\title{
KIRGANELIA RETICULATA (POIR) BAILL.: A REVIEW ON ITS BOTANY, ETHNOBOTANY, PHYTOCHEMISTRY AND PHARMACOLOGY
}

\author{
*Rajesh Kumar Soni ${ }^{1}$, Vihangesh Dixit ${ }^{1}$, Akanksha Chandra ${ }^{1}$, Raghuveer Irchhaiya ${ }^{1}$, Nandlal Singh ${ }^{1}$, Harsh Singh $^{2}$ \\ ${ }^{1}$ Institute of Pharmacy, Department of Pharmacognosy, Bundelkhand University, Jhansi (U.P.) India \\ ${ }^{2}$ Plant Diversity, Systematics and Herbarium Division, CSIR-National Botanical Research Institute, Lucknow, (U.P), India \\ *Corresponding author's: Tel: +918756696949, +918737001776, Email ID: rajeshsoni1987@gmail.com
}

\begin{abstract}
Kirganelia reticulata (Poir.) Baill. is known for its importance in various traditional medicine around the world and are proved pharmacologically as an antiviral against Hepatitis B, hepatoprotective, antidiabetic and antioxidant. In Ayurvedic system of Indian medicine recognized its activity against jaundice, diuretic, fever, liver disorder, in bleeding gums, small pox, syphilis, etc. The review summarizes the up-to-date and comprehensive information concerning the botany, traditional use, phytochemistry and pharmacology of important drug. Kirganelia reticulata and discusses the possible future scope for future research. In present review covers a literature survey across from 1826 to 2012. The some information collected from published literature on species of Kirganelia reticulata (Poir.) Baill. (=Phyllanthus reticulatus Poir.) and traditional ayurvedic texts. Phytochemical studies have shown the presence of many valuable compounds such as lignans, flavonoids, steroids, coumerins, triterpenes, phenols, flavonones, alkaloids are common compounds in test species. The extract and the compounds isolated from Kirganelia reticulata show a wide spectrum of Biological activities including antidiabetic, antibacterial, antioxidant, hepatoprotective, antiplasmodial, anticiceptive, analgesic and anti-inflammatory properties. Conclusion: The present review summarizes information concerning the morphology, ecology, ethanopharmacologically, phytochemistry, and traditional diseases and applications of $K$. reticulata. This review target at gathering the research work undertaken till date on this plant in order to provide sufficient baseline information for future works and commercial exploitation.

Keywords: Kirganelia reticulata, Ethnomedicinal, Phytochemical, Ethnopharmacology.
\end{abstract}

\section{INTRODUCTION}

Kirganelia reticulata (Poir) Baill. is belonging to the family Euphorbiaceae, popularly known as "potato plant or potato bush" and are variously named in different parts of the world. Synonymously, it is also named as Phyllanthus reticulatus Poir. and commonly used in Indian Ayurvedic system of medicine in various ailments related to liver, kidney, genitourinary system and stomach. It has properties of Rasa (Kashaya, Tikta, Madhura, Guna (Lakhu) and Veerya (Seeta). The ayurvedic literature has shown its wide utilization as in vata, pitta, diabetes, burning sensation, burns, skin diseases, obesity and urinary retention, skin eruption ${ }^{1}$. The use of this drug is now gaining momentum because of its novel antiviral activity against Hepatitis B virus and for several other biological activities such as hypotensive effects viral infections; hepatotoxicity causing liver diseases, jaundice ${ }^{2-8}$.

$K$. reticulata elaborates different class of organic compounds of, medicinal importance including alkaloids, flavonoids lignans, sitosterol, polyphenols, triterpenoids, saponins, coumerins phytosterols ${ }^{\text {9-12. }}$. The maximum number of phytochemical compound is present in leaves then stem and $\operatorname{root}^{\mathbf{1 3}}$. The present review assesses the potential of $K$. reticulata in relation to its traditional uses and in terms of finding based on modern bioscientific research. The link between conventional remedies and recent research in various areas has been well established in other plant derived products. The plant is known to contain several pharmacological important biomolecules whose well established in other plant derived products. Furthermore, this drug has several pharmacological important bio-molecules whose efficacy is well established by several biochemical and pharmacological studies. This review intent to compile various studies on this plant and critically evaluates the issues related to botany, traditional use in various parts of the world, phytochemistry and ethnopharmacology to highlights its importance in future research.

\section{TAXONOMY AND DISTRIBUTION}

Kirganelia reticulata (Poir) Baill. (=Syn. Phyllanthus reticulatus Poir.) is belonging to the family Euphorbiaceae. It is a large shrub growing in hedges, waste places and in forest. Leaves are usually ovate-oblong to elliptic, $1-5 \mathrm{~cm}$ long, $0.7-3 \mathrm{~cm}$ wide, produced on short lateral branchlets, looking like leaflets of a compound leaf. Flowers are borne in clusters on short axillary branchlets, small, yellowish, sexes separate on the same plant. The flowering shoots and pedicels are covered in short, velvety hairs. Fruit is berry-like, 4-6 mm across, blackish when ripe $^{\mathbf{1 4 , 1 5}}$. The flowering and fruiting season is during the month of March-July ${ }^{16-21}$.

This plant is widely distributed throughout the tropical countries of the world including India, Sri Lanka, the Himalayas, China, Indo-china, Malaysia, into tropical Australia and is supposed to also occur in tropical parts of Africa ${ }^{22-27}$. The name "Phyllathus means "leaf and flower" because the flower, as well as the fruit, seems to become one with the leaf. The genus (Euphorbiaceae) consists of about 6500 species in 300 genera, of which 200 are 
American, 100 African, 70 from Madagascar and the remaining Asian and Australasian ${ }^{28,29}$.
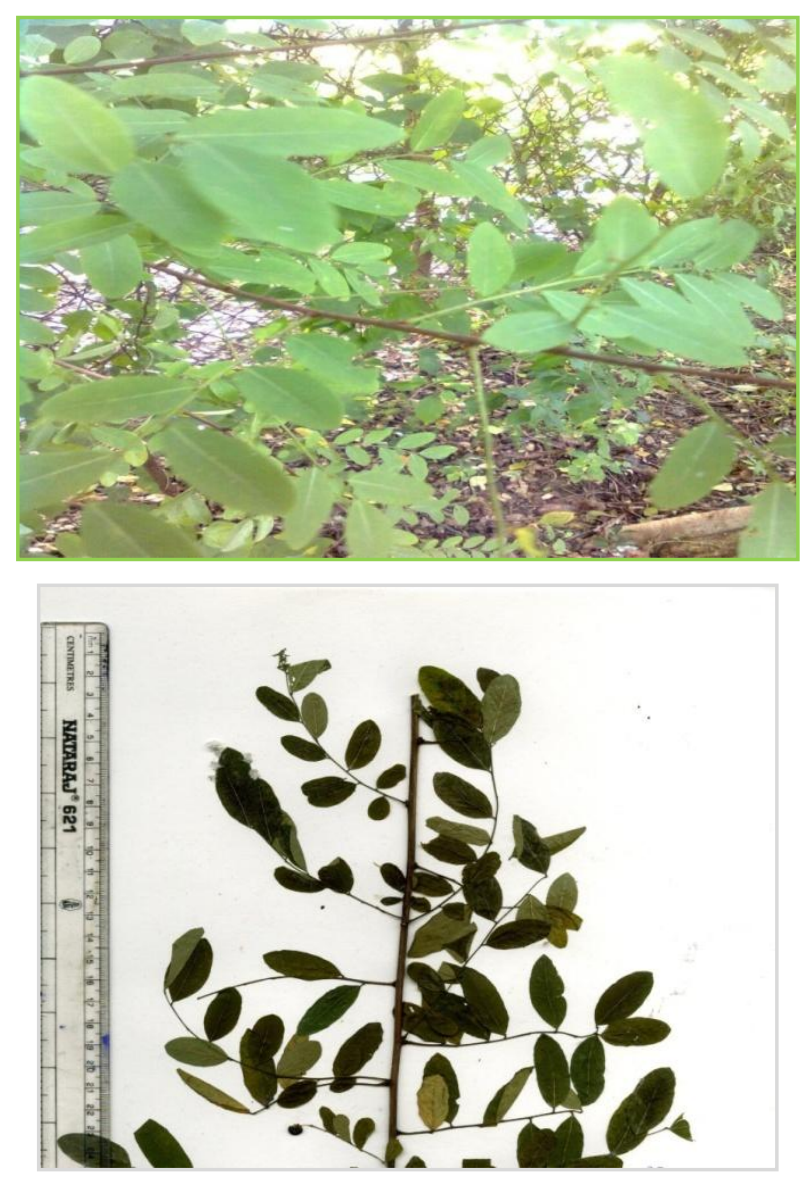

Figure 1: K. reticulata (Poir) Baill. plant.

\section{HISTORICAL PERSPECTIVE}

$K$. reticulata has been indexes in majority of published phytochemical, pharmacological and traditionally uses reviews and research articles till date with different named. In Poiret, 1804 is described this species based on a collection made by an unknown collector in tropical Asia and deposited in Lamarck herbarium in Paris. Although Poiret's protologue mentions that species grew "dans les Indes" the sheet no locality information and it is therefore unclear from where and from whom Lamarck received this plant. Given that the collection must have been made before $1804^{30-32}$. It is one of largest genera of the euphorbiaceae. It contains compounds known to be biologically active ${ }^{33}$.In 1985 , scientific research has identified within the genus potential sources of agents against cancer ${ }^{34}$ and hepatitis $B$ virus ${ }^{35-37}$. The objective of this review is to organize taxonomically all such citations as could be found. Ethnobotanical surveys were carried out in Bukoba Rural District to explore the traditional ethnomedical knowledge, the use and conservation of medicinal plants in the management of HIV/AIDS opportunistic infections and to determine whether levels of harvesting are sustainable. The district is currently an epicentre of HIV/AIDS and although over $90 \%$ of the population in the district relies on traditional medicines to manage the disease, this traditional knowledge still remains largely unknown. Human Immunodeficiency Virus (HIV)/ Acquired Immune Deficiency Syndrome (AIDS) is a major public health problem in many countries particularly those in sub-Saharan Africa. Hence in sub-Saharan Africa, traditional healers HIV/AIDS patients ${ }^{38}$. The traditional healers play a crucial role of providing primary health care by taking care of people living with HIV/ AIDS ${ }^{39,40}$. In 2006 , almost two thirds $(63 \%)$ of all persons infected with HIV/ AIDS in the world were living in sub-Saharan Africa $^{\mathbf{4 1}}$. Tanzania as it affects mostly the young and most economically productive population ${ }^{42}$. HIV/AIDS are susceptible to fungal and bacterial opportunistic infections that result from immunosuppression ${ }^{\mathbf{4 3}}$.It is one of the leading causes of deaths in Tanzania and worldwide ${ }^{44}$. The use of plants as ( $K$. reticulata) medicine is common to many cultures, and a number of advanced pharmaceutical drugs were derived from plants ${ }^{\mathbf{4 5}}$. Tanzania depends on traditional medicines for the management of various diseases including HIV/AIDS ${ }^{\mathbf{4 6}}$. In Rural area of Tanzania especially in bukoba district, suffer from HIV/AIDS ${ }^{47}$. Many plants species is using in HIV/AIDS diseases but one of most plant is $K$. reticulata used in treating various disease related to HIV/AIDS in Bukoba rural district, Tanzania. The leaves part of $K$. reticulata used in treated of chronic cough chronic diarrhoea, cryptococcal meningitis, Herper zoster, oral candidiasis, oral sores, skin infections, skin rashes, tuberculosis ${ }^{48}$. Some importent medicinal uses of $K$. reticulata species in differents countries worldwide such as Africa, Sudan, Kenya, Tanzania, Pakistan, Indochina, Philippines, Malay Peninsula, Australia, India and Sri Lanka respectively. Many diseases and traditional uses.

\section{VERNACULAR NAME AND TRADITIONAL USES}

In Table No. 1. \& Table No. 2. Lists showed the traditional uses, local names, modes of preparation and the induced effects.

In Indian folk medicine, the drug is used for different ailments including asthma, stomachic, diuretic, fever, and thirst, astringent, inflammation and carcinoma53. The leaves and bark are sweet and cooling and hence are used in constipation and urinary disorder while leaves juice is used for the treatment of diarrhoea in children ${ }^{\mathbf{5 1}}$. Decoction of bark is used as astringent, diuretic and alternative $\mathrm{e}^{54}$. For bleeding gums, pill of this drug along with camphor and cubebs is kept in the mouth ${ }^{19,55}$. In India, leaves juice of this drug are used in infant diarrhoea in the Lakhimpur district, Assam ${ }^{56-63}$. The roots are used in Madras as a red dye ${ }^{64}$. In Indo-china, the whole plant is used in the treatment of small pox and syphilis. The fruit is said to be eaten in the times of scarcity in E. Africa ${ }^{65}$. An ink is prepared from ripe fruits in the Philippines. In East Africa, fruits and roots are alleged to be used for criminal execution, eaten by stock animals ${ }^{\mathbf{6 5}}$ and also Digo and Swahili peoples (East Africa) are used root infusion for gonorrhoea, decoction as purgative other part of the medicine for hookworm ${ }^{\mathbf{6 6}}$. Mostly in Tanzania, Dried whole plant of $K$. reticulata is used in decoction for gonorrhoea $^{67,68}$. 
Table 1: Vernacular Name of K. reticulata (Poir) Baill.Worldwide

\begin{tabular}{|l|l|l|}
\hline S. No. & Language & Vernacular Name \\
\hline 1. & Bengali & Panjuli, Panseuli, Chitki, Pankushi, pan chitki. \\
\hline 2. & Sanskrit & Krishna-kamboji, Poolika. Kale madh \\
\hline 3. & Ayurveda & Kaamboji. \\
\hline 4. & Hindi & Panjuli, Buinowla, Makhi, Panjoli, \\
\hline 5. & Gujarati & Datwan and Kam-Boi \\
\hline 6. & Kannada & Anamsule, Chippulinellu, Huli, Karesuli, Karihuli. \\
\hline 7. & Konkani & Kaili \\
\hline 8. & Marathi & Pavan and Pavana, Panpoi \\
\hline 9. & Assamese & Amlakhi \\
\hline 10. & Oriya & Bonoti-Hudi, Jandaki, Jojangi or Phajoli. \\
\hline 11. & Punjabi & Panjuli. \\
\hline 12. & Tamil & Abiranji Civappuppula, Karunelli, Karuppupilanji or Nirppu-Lanji. \\
\hline 13. & Telugu & Nallapuli, Nal-Lapuruguda, Nellapurududu or Pandicarranlue \\
\hline 14. & Malayalam & Niroori, Niroli, Nirnelli. \\
\hline 15. & English & $\begin{array}{l}\text { Potato plant, Potato bush, Reticulated leaf- flower. Black-berried, featherfoil, } \\
\text { Black- honey shrub, Netted-leaved leaf-flower. }\end{array}$ \\
\hline 16. & Chinese & Xiao guo ye xia zhu. \\
\hline 17. & Phillipine & Malatinta, Tinatinaan, Tintatintahan(Tagalog)- sungot-olang (Bisaya), \\
\hline 18. & Indonesia & Matang-buiud, Tintatintahan.(Biak), wawulutan (Sundanese), trembilu, \\
& Congcong belut (Javanese), \\
\hline 19. & Central and Rural Tanzania & Kitukuto, Kaumura. \\
\hline 20. & African & Aartappelbos. \\
\hline 21. & IsiZulu & Umchumelo \\
\hline 22. & XiTsonga & Thethenya \\
\hline 23. & Intaba & Yengwe \\
\hline 24. & Thailand & Kaang plaa khruea, mat kham (northern), am aai (eastern). \\
\hline 25. & Kenyan & Mkwamba, \\
\hline 26. & Japanese & Shima komi kansou \\
\hline 27. & Vietnamese & Phèn đen, Diệp hạ châu mạng, Cây no, Kỏ kang pá. \\
\hline 28. & Malaysia & Kayu darah belut, tampal besi. \\
\hline 29. & Switzerland & Mchunguchungu, mfuungozi, mkasiri., mviongozi, Mwino, mzizima. \\
\hline 30. & Cambodia & Prâpénh chhmôôl. \\
\hline 31. & Laos & Am ai, kang pa. \\
\hline & & \\
\hline
\end{tabular}

\section{PHYTOCHEMISTRY}

The secondary metabolites present in $K$. reticulata are alkaloids, tannins, saponins, coumerins, sterol, triterpenoids, polyphenols, flavonoids, glycosides and essential oil ${ }^{12,13,69-75}$; flavonoids (tricin, quercetin, quercetrin, rutin, kaempferol etc. ${ }^{\mathbf{9 6}}$ Ellagitannins (geraniinic acid, corilagin, gallic acid, etc.) ${ }^{\mathbf{7 6 , 7 7}}$, titerpenoids (golchidonol, Stigmast-22-en-3-ol, stigmast-5en-3-ol, $21 \alpha$-hydroxyfriedel-4(23)-en-3-one etc. $)^{\mathbf{1 1 , 7 8}}$, sterols (stigmasterol, $\beta$-Sitosterol-3-O- $\beta$-glucoside, $\beta$ sitosterol, Stigmasta-5,6-dihydro-22-en-3 $\beta$-ol etc. $)^{\mathbf{9}, 10,76}$ and main lignans are reticulosides $A$ and reticulosides $\mathrm{B}^{\mathbf{7 9}}$. Some lignans and compounds isolated from $K$. reticulata as pentacosane, octacosane, lup-20(29)-en-3 $\beta$-24-diol, sorghumol and sorghumol acetate, friedelin, epifriedenol, kokoonol, $\beta$-sitosterol, taraxerone, teraxeryl acetate, $21 \alpha$ Hydroxyfriedelin-3-one, betulin, friedelan-3 $\beta$-ol, betulinic acid, $p$-comeric acid, ellagic acid, pyrogallic acid, pirorisinol $1^{9,10,70,75,78,80,81}$. The chemical screening of $K$. reticulata, extracted out had founded antiplasmodial ${ }^{\mathbf{8 2}}$, antidiabetic $^{83}$, antimicrobial and cytotoxic $^{69}$ and hepatoprotective ${ }^{\mathbf{8 4}}$. Bioactivities and also properties like isotachioside $^{85}$, epigallocatechin ${ }^{86}$, mananthoside ${ }^{87}$, carthamoside $\quad \mathrm{B}_{5}{ }^{88}, \quad$ hovetrichoside $\quad \mathrm{A}^{89}, \quad 3,4-$ dihydroxyphenylpropanol 3-O-D-glucopyranosides ${ }^{\mathbf{9 0}}$, turpenionosides $\mathrm{A}^{\mathbf{9 1}}$, isoguanine ${ }^{\mathbf{9 2}}$, respectively ${ }^{\mathbf{9 3}}$ and isolated from leaves of this plant three known compounds found under NMR analysis as lupeol, lupeol acetate and stigmasterol $^{94-97}$. Eight compounds, including two flavonoid glycosides, were isolated from the butanolsoluble fraction of the methanolic extract of the leaves of $K$. reticulate. The recently developed high-performance liquid chromatography solid-phase extraction-nuclear magnetic resonance (HPLC-SPE-NMR) technique, which has been demonstrated to be a powerful tool ${ }^{98-100}$, for identification and quantification of various chemical constituent in the plant material (reference of above technique used for this plant). The qualitative phytochemical analysis, conducted on $K$. reticulata crude drug samples, result positive reaction for various groups of chemical constituents and chemical structures given in the Table No. 3 \& 4 .

The terpenoids isolated from $K$. retculata are glochidonol, stigmast-22-en-3-ol, Stigmast-5-en-3-ol, Turpenionosides A, Turpenionosides B etc., flavonods such as quecertin, kaempferol, rutin, Isoquercirtin, astragalin, Quercetin 3-O$\alpha$-L-rhamnopyranoside etc., ellagitannins include geraniinic acid corilagin and sterol such as sitosterol, $\beta$ - 
sitosterol, Stigmasterol etc. $K$. reticulata had been reported to have pharmacological effect such as in antibacterial activities found a maximum inhibitory activity is exihibited by both methanolic and ethanolic extracts. The entire plant powder of $K$. reticulata shows good antioxidant activity of about $90.0 \%$ and antidiabetic activity shows weak potential in allaxon- induced diabetic mice. It exhibited hepatoprotective activities in rats against $\mathrm{CCl}_{4}$ - induced liver damage.

Table 2: Ethnomedicinal uses of $K$. reticulata (Poir) Baill. in different countries worldwide

\begin{tabular}{|c|c|c|c|c|}
\hline $\begin{array}{l}\text { S. } \\
\text { No }\end{array}$ & Region & Plant Part Used & Diseases and Uses & Ref \\
\hline 1. & West Africa & $\begin{array}{l}\text { Wood } \\
\text { Juice of stem } \\
\text { Twig } \\
\text { Leaves }\end{array}$ & $\begin{array}{l}\text { Threshing sticks and roof binders } \\
\text { Sore eyes } \\
\text { Chewsticks } \\
\text { Post-Partum treatment }\end{array}$ & 114 \\
\hline 2. & South Africa & $\begin{array}{l}\text { Twig } \\
\text { Powderd leaves } \\
\text { Leaves and Bark }\end{array}$ & $\begin{array}{l}\text { Chewsticks } \\
\text { Sore, burns, suppuration and Chafed areas } \\
\text { Diuretic or alterative foliage } \\
\text { Possibly eaten by stock }\end{array}$ & 115,116 \\
\hline 3. & $\begin{array}{l}\text { Zimbabwe(Eastern } \\
\text { Province of Northern } \\
\text { Zimbabwe; Chewa and } \\
\text { Nagoni people) }\end{array}$ & Whole plant & Anemia \& Intestinal hemorrhage & 117 \\
\hline 4. & East Africa & $\begin{array}{l}\text { Fruits } \\
\text { Roots and fruits } \\
\text { Roots and bark } \\
\text { Juice of plant }\end{array}$ & $\begin{array}{l}\text { Famine food } \\
\text { Some time eaten by stock animal, criminal execution } \\
\text { Red to black dye and poultary Blown into eyes for } \\
\text { soreness }\end{array}$ & 65,118 \\
\hline 5. & $\begin{array}{l}\text { East Africa } \\
\text { (Digo \& } \quad \text { Swahili } \\
\text { People) }\end{array}$ & Root infusion & $\begin{array}{l}\text { Gonorrhoea, Decoction, Purgative and part Of medicine } \\
\text { for Hookworm }\end{array}$ & 66 \\
\hline 6. & Sudan & Whole plant & Diuretic and refrigerant & 119 \\
\hline 7. & Kenya & Bark & Dying for tanning fishing lines & 120 \\
\hline 8. & $\begin{array}{l}\text { Northwestern Kenya } \\
\text { Turkan people }\end{array}$ & $\begin{array}{l}\text { Whole plant } \\
\text { Twig }\end{array}$ & $\begin{array}{l}\text { Eaten by camel, goat and sheep } \\
\text { Chewing sticks/toothbrushes }\end{array}$ & 120 \\
\hline 9. & Tanzania & $\begin{array}{l}\text { Whole plant } \\
\text { Dried Root } \\
\text { Dried bark, leaves } \\
\text { Arial parts } \\
\text { Fresh leaves, } \\
\text { powder } \\
\text { Dried fruits \& } \\
\text { roots } \\
\text { Fresh leaves juice } \\
\text { Dried root } \\
\\
\text { Dried root bark } \\
\text { Fresh twig }\end{array}$ & $\begin{array}{l}\text { Decoction for gonorrhoea } \\
\text { Decoction for dysmenorrhoea } \\
\text { Painful manstruration } \\
\text { Intestinal hemorrhage \& anemia } \\
\text { Burns \& sores } \\
\text { Criminal poisoning } \\
\text { Muscles spasms } \\
\text { Abscesses, decoction for Gonorrhoea, muscle spasms, } \\
\text { purgative, dysmenorrhea, diarrhea with anal bleeding, } \\
\text { infusion for hookworm. } \\
\text { Infusion for promoting Fertility } \\
\text { Chewstick }\end{array}$ & $\begin{array}{c}103,104 \\
122 \\
123\end{array}$ \\
\hline 10. & $\begin{array}{l}\text { Tanzania, near Lake } \\
\text { Victoria Sukuma people }\end{array}$ & Roots & $\begin{array}{l}\text { Pounded \& decoction drunk in } \\
\text { water for Headache }\end{array}$ & 124 \\
\hline 11. & $\begin{array}{l}\text { Tanzania } \\
\text { Masai Steppe } \\
\text { Zigua people }\end{array}$ & Roots & Boiled decoction drunk to increase male fertility & 124 \\
\hline 12. & Philippines & $\begin{array}{l}\text { Leaves/bark } \\
\text { Leaf powder } \\
\text { Bark } \\
\text { Roots } \\
\text { Fruit }\end{array}$ & $\begin{array}{l}\text { Infusion as a diuretic, Alterative, depurative (purifying } \\
\text { agent), refrigerants, and Odontalgic for toothachne, } \\
\text { Applied to the abdomen for pinworm, Made into the pill } \\
\text { with camphor for bleeding gums, } \\
\text { Sores and burns } \\
\text { Infusion for desentry, Diuretic, astringent } \\
\text { Infusion for asthama, juice for } \\
\text { infant diarrhoea, remedy for sore- eyes } \\
\text { Astringent to bowels and against } \\
\text { inflammations and blood disease }\end{array}$ & $\begin{array}{l}125,126 \\
124,127 \\
128\end{array}$ \\
\hline 13. & Australia & Fruits & Infusion, internal pain, itches, heat rush, chicken pox & 129 \\
\hline
\end{tabular}




\begin{tabular}{|c|c|c|c|c|}
\hline & $\begin{array}{l}\text { (not clear which species } \\
\text { of euphorbiaceae, or } \\
\text { perhaps all cited this } \\
\text { species was cited as a } \\
\text { possible synonym for } \\
\text { cecuringa } \\
\text { melanthesoides- } \\
\text { (F.Mull; H.K. Airy- } \\
\text { Shaw) }\end{array}$ & Young leaves & $\begin{array}{l}\text { several sickness, open sores \& leprosy } \\
\text { Applied locally for pinworm }\end{array}$ & \\
\hline 14. & Sri Lanka & $\begin{array}{l}\text { Bark } \\
\text { Root } \\
\text { Powdered leaves } \\
\text { Juice of leaves } \\
\text { Fruits }\end{array}$ & $\begin{array}{l}\text { Decoction used as astringent \& diuretic } \\
\text { Decoction for asthama } \\
\text { Sores, burns \& suppurations } \\
\text { Children's diarrhoea } \\
\text { In bowel inflammation, "disease of the blood" }\end{array}$ & 49 \\
\hline 15. & Pakistan (sind.) & Leaves & Diuretics and cooling medicine & $\begin{array}{l}57,60 \\
62\end{array}$ \\
\hline 16. & Indochina & Whole plant & Smallpox, syphillis,bleeding gums & 130,128 \\
\hline 17. & India, Indochina & Bark & Alterative & 131 \\
\hline 18. & Malay Penisula & $\begin{array}{l}\text { Stem \&leaves } \\
\text { Leaves }\end{array}$ & $\begin{array}{l}\text { Rubbed on chest for asthma } \\
\text { Decoction drunk for sore throat }\end{array}$ & $\begin{array}{l}132 \\
128\end{array}$ \\
\hline 19. & India & $\begin{array}{l}\text { Leaves } \\
\text { Bark }\end{array}$ & $\begin{array}{l}\text { Diuretic and cooling medicine } \\
\text { Decoction of four ounces twice or more daily as an } \\
\text { alterative, "attenuant" (allegedly To weak enthe effects of } \\
\text { a pathogen or drug), astringent to the Bowels; useful in } \\
\text { Inflammations and disease of blood (unSpecified) }\end{array}$ & 133 \\
\hline 20. & $\begin{array}{l}\text { India, Assam } \\
\text { Lakhimpur }\end{array}$ & Juice of leaves & Infant diarrhea & $\begin{array}{l}56,57 \\
58,59 \\
60,61 \\
63,64\end{array}$ \\
\hline 21. & $\begin{array}{l}\text { India Maharastra: } \\
\text { Konkan' Costal region }\end{array}$ & $\begin{array}{l}\text { Leaves } \\
\text { Juice of leaves }\end{array}$ & $\begin{array}{l}\text { Reduced to thin extract with other "alterative" plant and } \\
\text { made into pill With aromatics, this pill "rubbed down" in } \\
\text { milk, twicw daily made into pill with camphor and cubes } \\
\text { for bleeding gums. }\end{array}$ & $\begin{array}{l}57,134 \\
60,61,62\end{array}$ \\
\hline 22. & $\begin{array}{l}\text { India } \\
\text { East \& West coasts }\end{array}$ & $\begin{array}{l}\text { Root and root } \\
\text { bark } \\
\text { Leaves }\end{array}$ & $\begin{array}{l}\text { Decoction of } 4 \text { ounce twice daily alterative, for veneral } \\
\text { sores } \\
\text { infusion of } 1-2 \text { ounces astringent, diuretic, cooling }\end{array}$ & 134,61 \\
\hline 23. & India & Dry bark \&Leaves & Decoction as a diuretic, alterative and for cooling effect & \\
\hline
\end{tabular}

Table 3: Structures of isolated compounds and identified from K. reticulata (Poir) Baill.

\begin{tabular}{|c|c|c|c|c|}
\hline S.NO. & Chemical Name & Isolated from part & Ref \\
\hline 1. & $\begin{array}{c}\text { Astragalin } \\
\text { glucopyrano- side })\end{array}$ & Leaves & Structure \\
\hline 2. & Betulin & Roots and stems & & \\
\hline 3. & Betulinic acid & Stem \& Leaves &
\end{tabular}




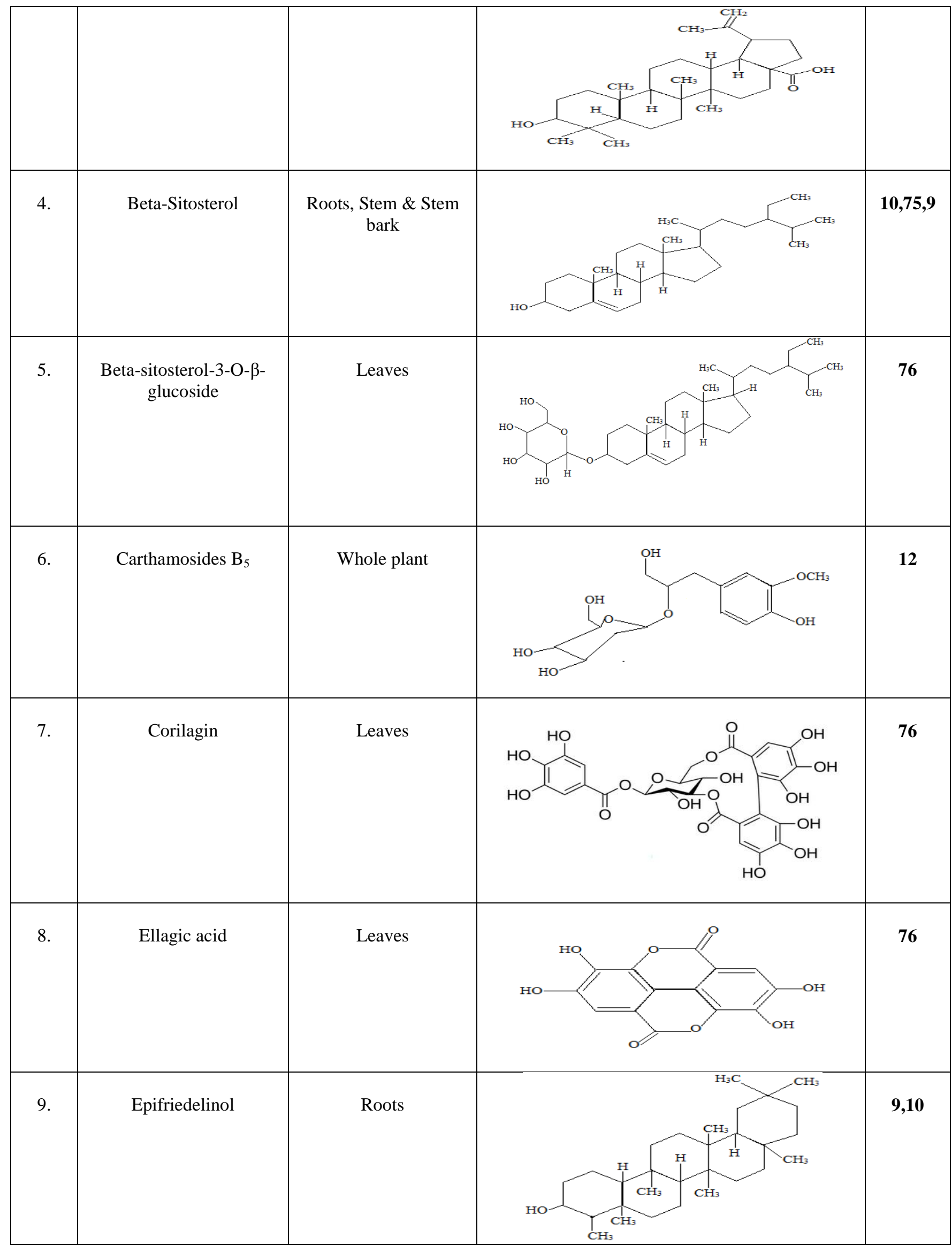




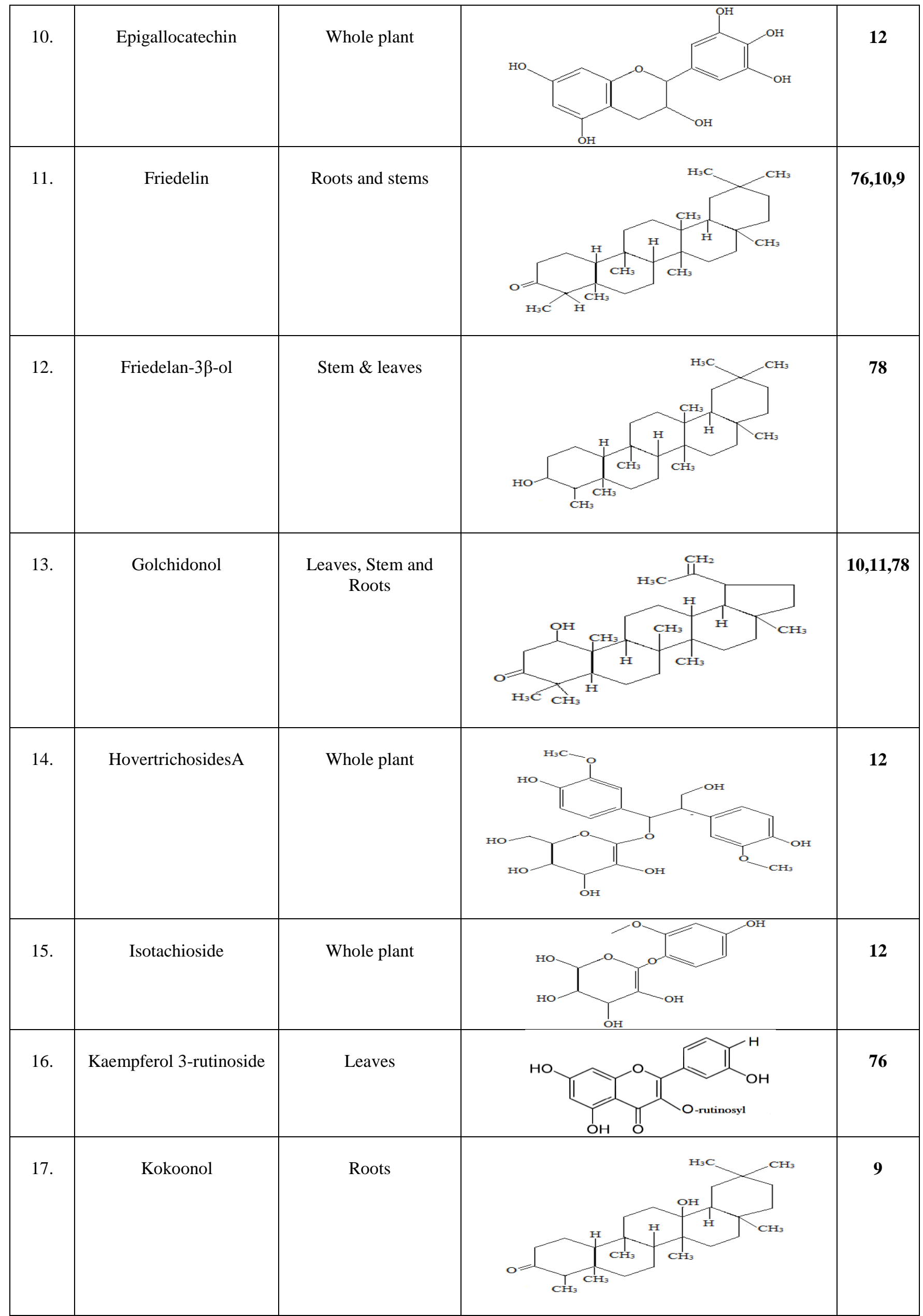




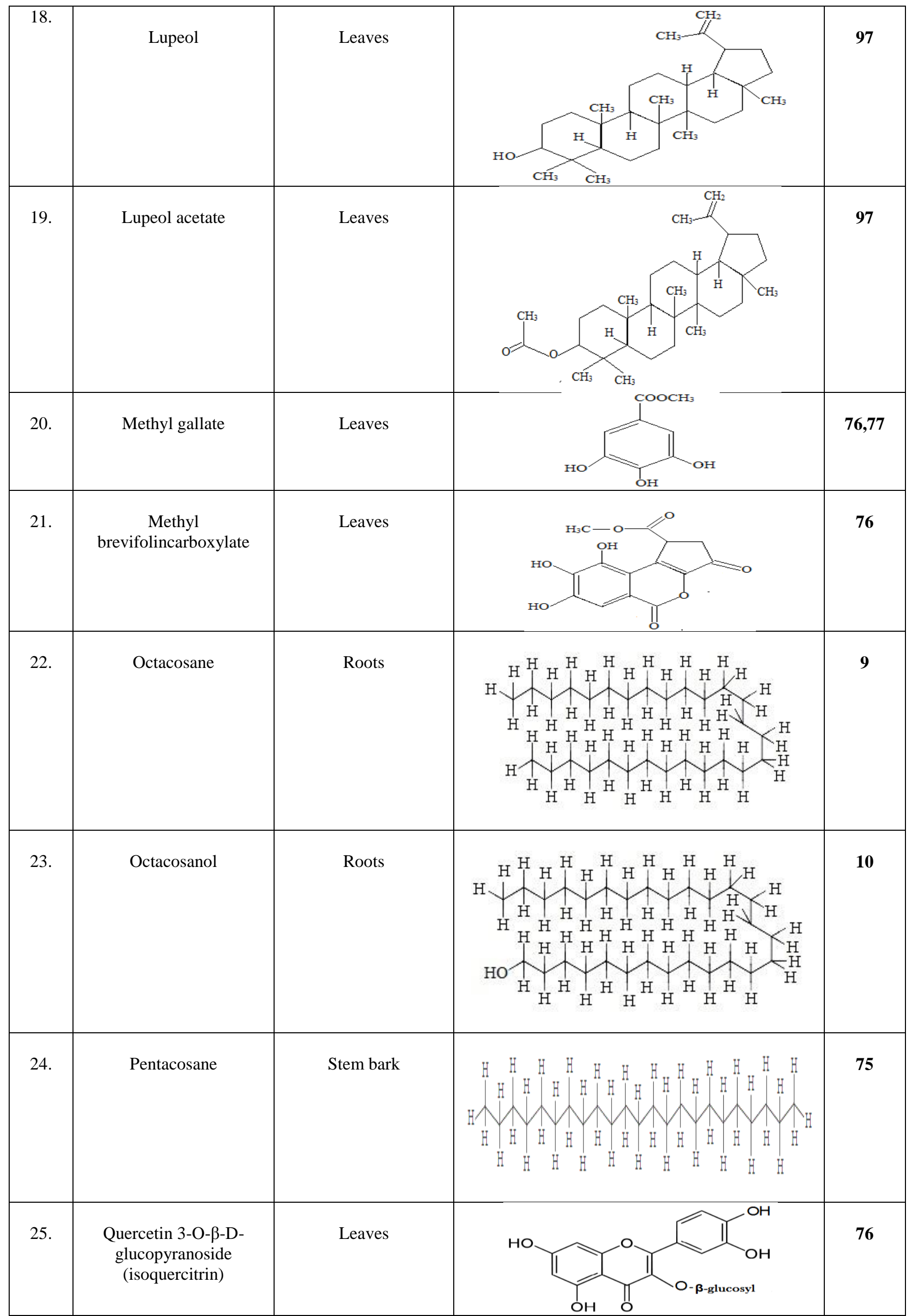




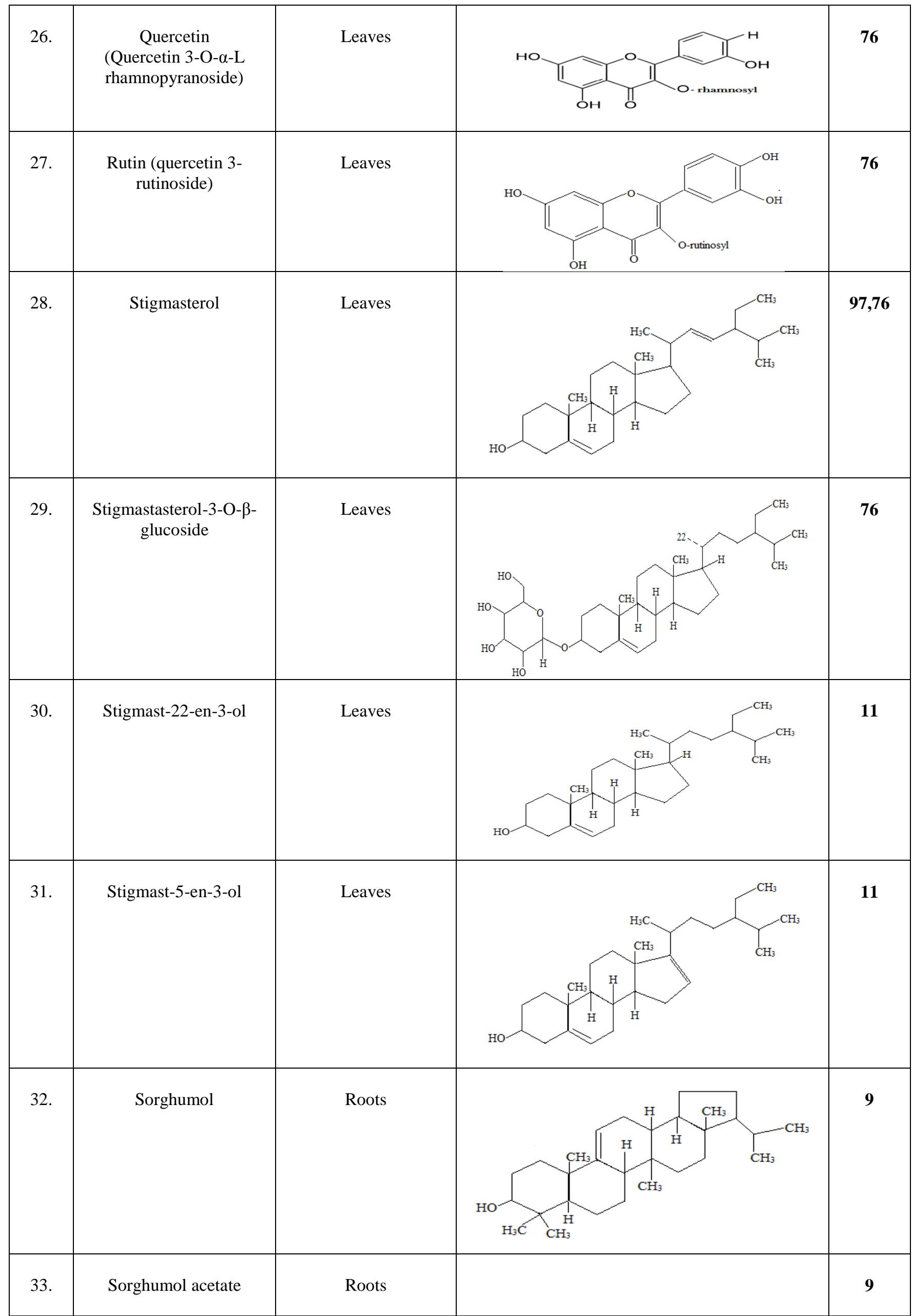




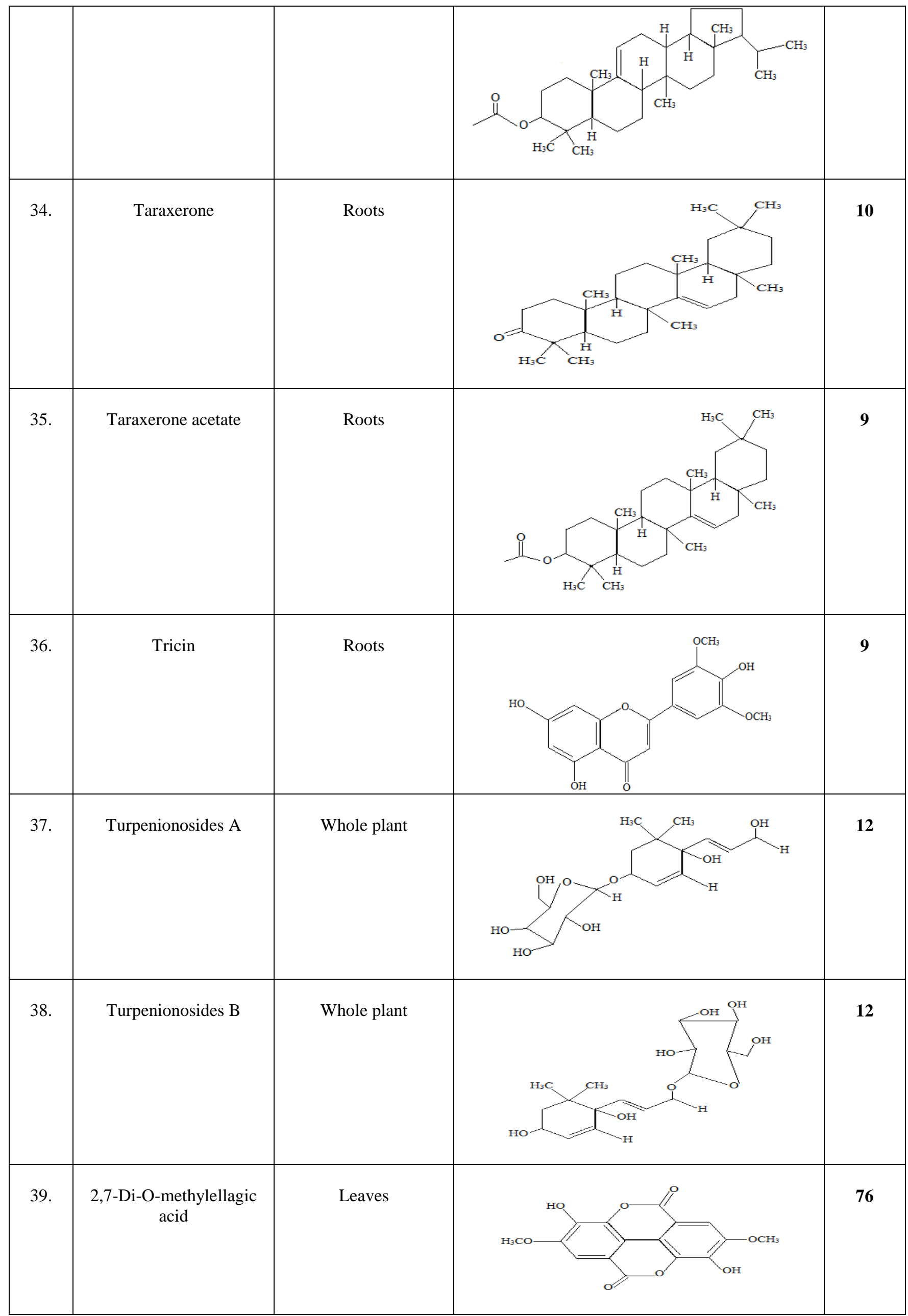




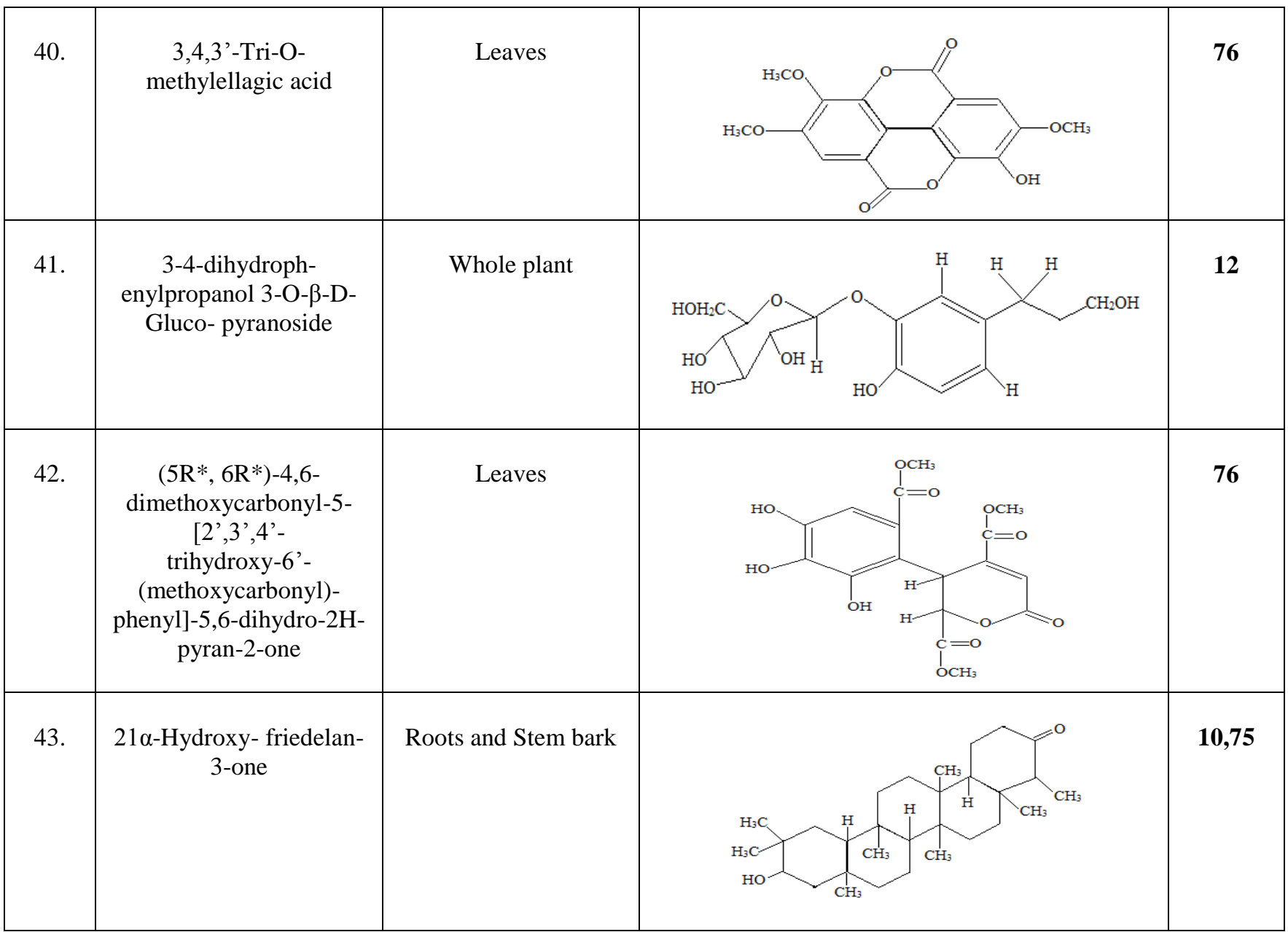

Table 4: Compounds present in $K$. reticulata throughout extractions: ${ }^{13,72}$

\begin{tabular}{|c|c|c|c|c|}
\hline \multirow[t]{2}{*}{ S.N. } & \multirow{2}{*}{$\begin{array}{c}\text { Solvent } \\
\text { Used }\end{array}$} & \multicolumn{3}{|c|}{ Compounds obtained from the plant } \\
\hline & & Leaf & Stem & Root Bark \\
\hline 1 & Pet. Ether & $\begin{array}{l}\text { alkaloids, carotenoids, coumerins, } \\
\text { dihydrochalcones, steroids }\end{array}$ & ------ & ----- \\
\hline 2 & Methanol & $\begin{array}{l}\text { alkaloids, anthocyanins, anthocyanidins, } \\
\text { catacholic compounds, coumarins, } \\
\text { dihydrochalcones, emodins, flavonoids, } \\
\text { flavones, glycosides, lignans, phenols, } \\
\text { triterpenoid }\end{array}$ & $\begin{array}{l}\text { alkaloids, anthocyanins, } \\
\text { flavonoids, flavonols, } \\
\text { glycosides, phenols, } \\
\text { saponins, triterpenoids }\end{array}$ & $\begin{array}{l}\text { alkaloids, anthocyanins, } \\
\text { antraceneglycosides, } \\
\text { flavonoids, flavonols, } \\
\text { glycosides, phenols, } \\
\text { triterpenoids }\end{array}$ \\
\hline 3 & Water & $\begin{array}{l}\text { alkaloids, anthocyanins, coumarins, } \\
\text { dihydrochalcones, emodins, flavonoids, } \\
\text { flavones, phenols, Saponins triterpenoid }\end{array}$ & $\begin{array}{l}\text { alkaloids, } \\
\text { antraceneglycosides, } \\
\text { flavonoids, flavonols, } \\
\text { glycosides, triterpenoids }\end{array}$ & $\begin{array}{l}\text { Alkaloids, flavonoids, } \\
\text { flavones, glycosides, } \\
\text { saponins, triterpenoids }\end{array}$ \\
\hline
\end{tabular}

\section{ETHNOPHARMACOLOGICAL ACTIVITY}

In worldwide, the plant was reported for various ethnopharmacological activities such as tumor-promoting activity found (Hecker, personal communcitation); ${ }^{101}$ hypotensive activity ${ }^{\mathbf{1 0 2}}$ antifungal and in vitro Hypotensive activity $^{\mathbf{6 7}, 10,103}$ etc. These are described as following:

6.1. Antidiabetic activity, Anti- hyperglycaemic And hypoglycaemic activities

The plant $K$. reticulata is claimed to have antidiabetic activity in tribal area. To validate the tribal claim, the petroleum ether and ethanolic extracts of leaves of the $K$. reticulata were orally tested at 500 and $1000 \mathrm{mg} / \mathrm{kg}$ for hypoglycaemic effect in alloxan induces diabetic mice. It shows antidiabetic activity at the dose of $1000 \mathrm{mg} / \mathrm{kg}$. The phytochemical screening of the residues revealed the presence of terpenoids glycosides, protein, carbohydrates and absence of alkaloids and steroids ${ }^{\mathbf{8 3 , 1 0 5 , 1 0 6}}$.

\subsection{Antibacterial activities}

The in vitro antibacterial activities of leaf extract (Methanol and Ethanol) from 10 genus species. Which are medicinally important, were investigated by agar-well diffusion method against four food borne human pathogens (Staphylococccus aureus, Salmonella typhi, Vibrio cholera and Pseudomonas aeruginosa). Leaf extracts contained high level of phenols and exhibit differential antibacterial 
activity against all four tested human pathogenic bacteria. The phenolic constituents of the tested extracts are closely associated with antibacterial activity. Highest antibacterial activity is exhibited by $K$. reticulata and can be used as a promising source of antibacterial drug ${ }^{107}$, methanol, chloroform and hexane extracts from leaves of $K$. reticulata, used in Indian ayurvedic medicine for the treatment of several ailments of microbial and nonmicrobial origin were evaluated for potential antibacterial activity against methicillin- isolated from clinical specimen was studied. The minimum inhibitory concentration (MIC) and minimum bactericidal concentration (MBC) resistant Staphylococcus aureus (MRSA). Antibacterial activity and biofilm production of crude extracts against MRSA (ATCC 25923) values of the methanol, chloroform and hexane extracts were in the range of 12.5 to $50.0 \mathrm{mg} / \mathrm{ml}$ and 25.0 to $100.0 \mathrm{mg} / \mathrm{ml}$, respectively. Amongst the evaluated extracts, the methanolic extract showed the strongest antibacterial effect as well as biofilm inhibition. Micro plate screening used for detection of biofilm formation by Staphylococci is a quantitative model to study its adherence level and has been a sensitive method ${ }^{\mathbf{1 0 8}}$. and the in vitro antibacterial activity of crude methanolic, chloroform and hexane extracts of the leaves of $K$. reticulata were investigated. Susceptibility of some Gram-negative organisms (Escherichia coli, Pseudomonas aeruginosa, Salmonella typhi) and Gram-positive organism (Staphylococcus aureus) were tested. Agar well diffusion and broth dilution methods were used to determine the minimum antibacterial activity against all the tested microorganisms. The extracts exhibited antibacterial activities with zones of inhibition ranging from 9.07-30.10 $\mathrm{mm}, 8.17-24.57 \mathrm{~mm}$ and 5.60$14.67 \mathrm{~mm}$ for methanol, chloroform and hexane extracts respectively. Screening of crude extracts showed notable minimum inhibitory concentration (MIC) and minimum bactericidal concentration (MBC) at concentrations of 100 to $6.25 \mathrm{mgml}^{-1}$. The organisms were more sensitive to the methanolic extract of the leaves, where as extracts from other solvents like chloroform and hexane showed moderate to weak activity respectively. Similar results have been showed in MIC and $\mathrm{MBC}^{\mathbf{1 6}}$.

\subsection{Antioxidants activities and Free radical scavenging}

Antioxidant activity of entire plant of $K$. reticulata by performing different in vitro antioxidant assays, including 2,2-Diphenyl-1- Picrylhydrazyl (DPPH) radical scavenging, beta-carotene bleaching, superoxide anion radical scavenging, reducing power and metal chelating assay at different concentrations (100, 200 and 400 $\mu \mathrm{g} / \mathrm{ml})$. The entire plant powder of $K$. reticulata shows good antioxidant activity of about $90.0 \%$ when compared with standard butylated Hydroxy Toluene (BHT) $(85 \%)$ at a concentration of $400 \mu \mathrm{g} / \mathrm{ml}$. Results obtained reveal that methanolic extracts of entire plant of $K$. reticulata tapossess higher antioxidant activity when compared when compared with ethanolic extract. Thus, this study suggests that $K$. reticulata plantcan be used as a potent source of nature antioxidants ${ }^{\mathbf{1 0 9}}$, Free radicals are implicated for many diseases including Diabetes mellitus, arthritis, cancer, ageing. etc. In treatment of these diseases, antioxidant therapy has gained utmost importance. $K$. reticulata popularly important medicinal plant. Keeping in view of the cited activity, it is contemplated to screen the plant for in vitro antioxidant activity using different models viz. DPPH radical scavenging, ABTS radical scavenging, iron chelating activity and lipid peroxidation assay, nitric oxide scavenging assay, alkaline DMSO assay, total antioxidant capacity and non- enzymatic haemoglobin glycosylation assay. The results were analyzed statistically by regression method. Its antioxidant activity was estimated by IC50 value and the values are $20.36 \mu \mathrm{gm} / \mathrm{ml}$ (DPPH radical scavenging), $42.59 \mu \mathrm{gm} / \mathrm{ml}$ (ABTS radical scavenging), $32 \mu \mathrm{gm} / \mathrm{ml}$ (Iron chelating activity) and $41.91 \mu \mathrm{gm} / \mathrm{ml}$ (lipid peroxidation), 122.8 $\mu \mathrm{gm} / \mathrm{ml}$ (nitric oxide scavenging) and $2.57 \mu \mathrm{gm} / \mathrm{ml}$ (alkaline DMSO). In total antioxidant capacity assay, $1 \mathrm{mg}$ of extract is equivalent to $51 \mu \mathrm{g}$ of ascorbic acid. It showed $66.64 \%$ inhibition of haemoglobin glycosylation. In all the testing, a significant correlation existed between concentrations of the extract and percentage inhibition of free radicals, metal chelation or inhibition of lipid peroxidation. The antioxidant property may be related to the polyphenols and flavonoids present in the extract. These results clearly indicate that $K$. reticulata is effective against free radical mediated diseases ${ }^{\mathbf{1 1 0}}$, antioxidant properties of the medicinal plant $K$. reticulata. The different solvent extracts of $K$. reticulata leaves were screened for their in vitro phytochemical and antioxidant activity. Leaves were extracted with solvents of different polarities like aqueous, ethanol, methanol, chloroform, acetone and hexane. The distributions of the main active principles such as alkaloid, flavonoids, phenols, steroids tannins etc. present in the plant were analyzed. It was also focused to determine the total phenolic and flavonoid content present in the extracts. Extracts showed promising results for total antioxidant capacity and reductive capability when compared with standard drug. The ethanol extract was found to possess excellent phytochemical and antioxidant activities. The antioxidant property may be attributed to the presence of flavonoids and phenolics present in the drug. The ability of the crude extracts of $K$. reticulata towards reduction, presence of phenol, flavonoid and antioxidant is an indication of its broad spectrum potential which may be employed in the management of various diseases ${ }^{72}$. Many plants possess antioxidant ingredients that provided efficacy by additive or synergistic activities. Antioxidant activity of the methanol crude extract of entire plant of $K$. reticulata was assessed using DPPH, superoxide anion and metal chelating assays at different concentrations. The potent extract of $K$. reticulata was tested for in vivo efficacy. The methanol extract exhibited potent antioxidant activity compared to known antioxidant. In vivo studies on potent extract of $K$. reticulata demonstrated dose dependent reduction in hepatic malondialdehyde (330.70, 279.40 and383.79 $\mu \mathrm{Mmg}-1$ protein) with simultaneous improvement in hepatic glutathione (7.03, 18.16 and $6.88 \mu$ gmg-1 protein) and catalase levels (678.10, 787.00 and $522.00 \mu \mathrm{gmg}-1$ protein) respectively for $50,100 \mathrm{mgkg}$ 1 dose and control) compared to control group. Due to its natural origin and potent free radical scavenging ability $K$. reticulata could be used as a potential preventive intervention for free radical mediated diseases ${ }^{\mathbf{1 1 1}}$.

\subsection{Antiplasmodial activity}

Antiplasmodial of $K$. reticulata medicinal plants were extracted and tested for in vitro antiplasmodial activity 
against chloroquine- sensitive (K67) and chloroquineresistant (ENT36) strains of Plasmodium falciparum. Out of 16 extracts, 12 were active against ENT36 strain while seven were active against K67 strain, that is, IC50 < or = 50 micrograms $/ \mathrm{ml}$. The most active extracts on both strains were those of leaves of $K$. reticulata with IC50 < or $=10$ micrograms $/ \mathrm{ml}$. The stembark of Terminalia spinosa Engl. (Combretaceae) and the stems of Dissotis brazzae Cogn. (Melastomataceae) had IC50 < or $=10$ micrograms $/ \mathrm{ml}$ for strains K67 and ENT36, respectively. A phytochemical analysis of these plants revealed the presence of different classes of primary and secondary metabolites ${ }^{\mathbf{8 2}}$.

\subsection{Antinociceptive activity}

$K$. reticulata is used in folk medicinal practices of Bangladesh as an antinociceptive (reducing sensitivity to painful stimuli). The study was to investigate the antinociceptive activity of methanolic leaf extract of $K$. reticulata in Swiss albino mice. A model of acetic acidinduced gastric pain in mice was utilized to determine the antinociceptive effects. In writhing assays induced by acetic acid, the methanolic leaf extract showed significant inhibition compared to control. The maximum writhing inhibition (39.1\%) was found at a dose of $200 \mathrm{mg}$ extract/kg body -weight which, however, was lesser than that of the antinociceptive drug, aspirin (50.4\%), when used at a dose of $200 \mathrm{mg} / \mathrm{kg}$ body weight. Maximum tolerance $(35.0 \%)$ was showed at $400 \mathrm{mg}$ extract $/ \mathrm{kg}$ body weight, compared to that of the standard drug, glibenclamide at $10 \mathrm{mg} / \mathrm{kg}$ body weight $(57.8 \%)$. The methanol extract of $K$. reticulata leaves had beneficial effects as a pain reliever which validates the use of the plant in Bangladesh folk medicinal practices as a treatment for pain ${ }^{106}$

\subsection{Analgesic activity}

The petroleum ether, ethyl acetate, and methanol extracts of $K$. reticulata were chosen for pharmacological screening. In the acetic acid-induced writhing test, the ethyl acetate extract in doses of 150 and $300 \mathrm{mg}=\mathrm{kg}$ showed 51.23 and $65.12 \%$ inhibition of writhing, respectively. A significant elongation of tail-flick time was evident both in the ethyl acetate and the methanol extracts (42.38 and 60.49\%) only at the $300 \mathrm{mg}=\mathrm{kg}$ dose level. The extracts of $K$. reticulata possess significant shows analgesic properties ${ }^{\mathbf{1 1 2}}$.

\subsection{Antiviral activity}

$K$. reticulata is a reputed medicinal plant used in Bangladesh and India for the treatment of gastric complaints including colic, constipation etc. The study was to evaluate the antiviral activity of this plant against hepatitis $\mathrm{B}$ virus (HBV) using $\mathrm{HBsAg}$ positive serum sample from hepatitis B virus infected patients. Two semipurified organic fractions designated as PR1 and PR2 of the fat free ethanolic extract were tested at both lower and higher concentrations $(20 \mathrm{mg} / \mathrm{ml}$ and $40 \mathrm{mg} / \mathrm{ml}$ respectively) for their anti hepatitis $B$ virus surface antigen (anti-HBsAg) activity using an in vitro system by Reverse Passive Haemagglutination (R-PHA) method. SERRODIA-Anti-HBsAg- Diagnostic kit was used for detection of Anti-HBsAg antibody. Both fractions showed anti-HBsAg activity. But it was found the fractions have little inhibitory action on HBsAg at lower concentration whereas at the higher concentration they have prominent inhibitory action on the antigen. To the best of our knowledge this is the first report of the antiviral activity of $K$. reticulata against $\mathrm{HBV}$. The Anti-HBsAg. activity observed by the fractions may be due to the binding of the agents with the antibody binding sites present on HBsAg. Thus the fractions might be the potential sources of the active principles responsible for antiviral activity ${ }^{\mathbf{5 3}}$.

\subsection{Anti-inflammetry activities}

To study pharmacognostic evaluation and anti inflammatory activity of $K$. reticulata fruit. The hydroalcoholic extract of ripe fruits and petroleum ether, ethyl acetate, and methanolic extracts of aerial parts was also screened for anti-inflammatory activity by carrageenan induced left hind paw oedema in rat at doses of $200 \mathrm{mg} / \mathrm{kg}$ and $400 \mathrm{mg} / \mathrm{kg}$, orally ${ }^{112,113}$.

\subsection{Insectisidal activities}

Chemical constituents as well as insecticidal activity of the crude methanol extract from the leaves of $K$. reticulata. Were investigated. $\left(5 R^{*}, 6 R^{*}\right)-4$, Dimethoxycarbonyl-5[2',3',4'-trihydroxy-6'-(methoxycarbonyl) phenyl]-5,6dihydro- $2 H$ pyran-2-one along with 3,4,3'-tri$O$ methylellagic acid, and methyl gallate were isolated from the dichloromethane extract. Determination of their structures was based on spectroscopic analysis. Compound 1 possessed a very weak insecticidal activity against Spodoptera frugiperda (Sf9) with an IC50 value of 27.27 $\mu \mathrm{g} / \mathrm{mL}^{77}$.

\subsection{Hepatoprotective activity}

Two partially purified organic fractions designated by PR1 and PR2 of the fat free ethanol (95\%) extract of aerial parts of $K$. reticulata were tested for the hepatoprotective activity in rats against $\mathrm{CCl} 4$-induced liver damage. The rats receiving the fractions showed promising hepatoprotective activity as evident from significant changes of pentobarbital-induced sleeping time, changes in serum levels of sGPT, sGOT, sALP and bilirubin and also from histopathological changes as compared to $\mathrm{CCl} 4$ intoxicated rats ${ }^{84}$.

\subsection{Toxicity}

The hexane and methanol extracts of $K$. reticulata leaves were inactive in the in vitro cytotoxicity study. The dichloromethane extract showed IC50 values of 11.89 $\mu \mathrm{g} / \mathrm{mL}$ in $\mathrm{KB}$ and $16.08 \mu \mathrm{g} / \mathrm{mL}$ in MCF7, but was inactive in the NCI-H187 human tumor cell line. The dichloromethane extract was then further purified using column chromatography, Two other compounds isolated from the dichloromethane extract were identified as 3,4,3'tri-Omethylellagic acid, and methyl-3,4,5trihydroxybenzoate (methyl gallate) by the spectrometric methods $^{77}$.

\section{CONCLUSION}

The scientific research on $K$. reticulata suggests a huge biological potential of this plant. It is strongly believed that detailed information as presented in this review on the phytochemical and various biological properties of the 
plant might provide detailed evidence for the use of this plant in different diseases. It has various traditional uses that differ from one country to another whereas some important uses for the treatment of diabetes, dysentery, fever, gonorrhoea, syphilis and stomachache and skin diseases are almost common. $K$. reticulata, a potent herbal medicine is attracting researchers since many decades due to its high therapeutic value. There is a demand to standardize the properties of $K$. reticulata and their detailed clinical trials. Pharmacological and chemical studies have demonstrated that the extracts of the plant possess various pharmacological actions viz. antiviral, anti-inflammatory antimicrobial, antidiabetic, hepatoprotective and antioxidants, antihepatitis $\mathrm{B}$, and antiplasmodial. Owing to the impressive precli- $2 H$-nical therapeutic potential, the plant extracts have been evaluated in human trials for the treatment of HIV, AIDS, hypertension and diabetes. $K$. reticulata is reported to contain lignans, flavonoids, polyphenols, triterpenes, sterols and alkaloids. The phytochemicals exhibited different structural characteristics with various pharmacological actions. The lignans glycosides isolated from $K$. reticulata significantly inhibited alloxon induced diabetic mice. The presence of high contents of phenolic compounds in the aqueous extract of $P$. reticulatus was found to have strong and significant antioxidant activity. Triterpenoids isolated from aqueous and methanolic extract of leaves, stem bark and root bark of $K$. reticulata exhibited very high antioxidant activity. Phytochemical and phytoanalytical information appears to be very useful

\section{REFERENCES:}

[1] Warrier PK, Nambiar VPK, Ramankutty C. Indian Medicinal Plants-a compendium of 500 species, Orient Longman Ltd, Madras. 2003; 4: 264-265.

[2] Rav MRR, Siddiqui HH. Screening of Indian plants for biological activity. Indian J Exp Biol 1964; 2: 49.

[3] Anjenenlu, ASR, Jagonmohon R. Subramanyam C. Isolation and structural elucidation of three new lignans from the leaves of Phyllanthus niruri Linn. Tetrahedron 1973; 29: 1291.

[4] Yoshida T, Seno K, Takama Y, Okanda T. Tannins and related polyphenols of Euphorbiaceous plants. Phytochemistry 1982; 21:1180.

[5] Sherlock S. (1981). Diseases of the liver and Biliary System. Blackwell Scientific Publication, Oxford, London, Edinburgh, Boston, Melbourne, 6th edition, p. 244.

[6] London WT and Blumberg BS. 1982. Hepatology. 2, 105145.

[7] Satyavati GV, Gupta AK. Medicinal Plants of India. New Delhi, 1987; 2: 345

[8] Unander DW, Herbert HB, Connete JL, Robert TM. Cultivation of Phyllanthus amarus and evaluation of variable potentially affecting yield and the inhibition of viral DNA polymerase. Economic Botany 1993; 47: 79-88.

[9] Jain R, Nagpal SI. Chemical Constituents of the roots of Kirganelia reticulata. J Indian Chem Soc 2002; 79: 776-777.

[10] Joshi KC, Singh P, Mehra A. Crystalline components of the roots of Phyllanthus reticulatus. J Indian Chemical Soc 1981; 58: $102-103$.

[11] Jamal A, Nasser WA, Yaacob LBD. Triterpenoids from Phyllanthus Reticulatus, Int Confer Appl Chem Pharma Sci 2012; 19-20

[12] Sheng ML, Xiong JM, Heng CT, Wei S, Zhu DY, Chemical Constituents of Phyllanthus reticulatus, Verlag Helvetica Chimica Acta 2010; 93: 2276-2280.

[13] Venkata Raju RR, Narasimhudu CL. Phytochemical constituents of Phyllanthus species (Euphorbiacae) from and might lead to development of novel agents for various disorders and could be explored further for commercial purposes. However, there are many aspects, which need to be explored like well-controlled clinical trials using large sample size (large number of patients) for the efficacy and toxicity, the mechanism of biological activity of active constituents present in the plant. On the basis of biological activities of $K$. reticulata, crude extract and derived phytochemicals and their uses as pharmacological agents in traditional and modern research are possible but will first require more clinical trials and product development. The current evidence is large limited to correlation between identified phytochemicals and mode of action for any pharmacological activity. Mechanism of action studies are expected to lead the way in the discovery of new agents with improved and intriguing pharmacological properties. This could be achieved by molecular modeling studies involving interaction of bioactive phytochemicals from $K$. reticulata with their respective molecular targets and the extract of $K$. reticulata could be further explored in the future as a source of useful phytochemicals for the pharmaceutical industry.

\section{ACKNOWLEDGEMENT:}

The authors are acknowledged to N.B.R.I. Lucknow (U.P), India. Providing to all literature Survey and also thanks to Institute of Pharmacy, Department of Pharmacognosy Bundelkhand University Jhansi (India), to help and supporting all time for preparation of manuscript.

Eastern Ghats of Andhra Pradesh, India. Int Res J Pharma 2012; 3(5): 184-200.

[14] Kathriarachchi H, Samuel R, Hoffmann P, Mlinarec J, Wurdack KJ. et al. Phylogenetics of the tribe Phyllantheae (Phyllanthaceae; Euphorbiaceae sensu lato) based on nrITS and plastid matK DNA sequence data. American J Botany 2006; 93: 637-655.

[15] Kathriarachchi H, Hoffmann P, Samuel R, Wurdack KJ, Chase MW. Molecular phylogenetics of Phyllanthaceae inferred from five genes (plastid $a t p B$, matK, $3^{\prime} n d h F, r b c L$ and nuclear PHYC ), Molecul Phylogene Evolu 2005; 36: 112 -134 .

[16] Shruthi SD, Ramachandra YL, Padmalatha RS, Shetty VA. Antibacterial potential of leaf extracts from Kirganelia reticulata Baill. Int J Pharma Res develop 2010; 2(6): 1-7.

[17] Whitmore TC. (1972)Tree Flora of Malaya - A Manual for Foresters Vol 1\&2. Longman, Malaysia.

[18] Turner, IM. Acatalogue of the vascular plants of Malaya. Gardens'Bulletin Singapore. 1995; 47(2):642-655.

[19] Kirtikar KR, Basu BD. (1980) Indian Medicinal Plants. Singh B, Singh MP, 2nd ed. Dehradun, India, pp. 2219-2220.

[20] Kritikar KR, Basu BD. (2003) Indian medicinal plants $2^{\text {nd }}$ ed vol. 9, International Book Distributors, Dehradun, pp. 3060.

[21] Gopalakrishna KB. (2003) Flora of Udupi, $1^{\text {st }}$ ed., Indian Naturalist, Udupi. pp. 578.

[22] Müller J. (1866) Euphorbiaceae excl. Euphorbieae. pp. 1891288 in Prodromus systematis naturalis regni vegetabilis $15^{\text {th }}$ ed. Candolle Ad. 2: 1143-1146. Paris: Masson.

[23] Smith AR. (1987) Euphorbiaceae (Part), in Flora of tropical East Africa; R.M. Polhill. Rotterdam and Boston :Balkema .

[24] Welzen VPC. (1997). Malesian Euphorbiaceae Newsletter 6. Leiden: Rijsksherbarium / Hortus Botanicus Leiden, the Netherlands. Available online at http://www.nationaalherbarium.nl/euphorbs/ Newsletter/Newsletter6.htm. 
[25] Govaerts R, Frodin DG, Radcliffe-Smith, A. (2000) World checklist and bibliography of Euphorbiaceae and Pandanaceae; Kew: The Royal Botanical Gardens.

[26] Balakrishnan NP, Chakrabarty T. (2007) The family Euphorbiaceae in India: Bishen Singh Mahendra Pal Singh, Dehradun.

[27] Li PT, Gilbert MG. (2009) Phyllanthus pp. 180-190 in Flora of China vol. 11, ed. Wu ZY, Raven PH, Hong DY. Beijing: Science Press; St Louis: Missouri Botanical Garden Press. Online at http:/ www.efloras.org/florataxon.aspx?flora_id=2\&taxon_id=1251 79.

[28] Nielsen HLB. (1979) Comments on the distribution and evolution of the genus Phyllanthus (Euphorbiaceae), p. 277290. In: K. Larsen and L.B. Holm- Nielsen (Eds.). Tropical botany. Academic Press, New York.

[29] Webster GL. (1956-58) A monographic study of the West Indian species of Phyllanthus. J. Arnold Arbor. 37:91-122, 217-268, 340-359; 38:51-80, 170-198, 295-373;39:49-100, 111-212.

[30] Shi-Xiao L, Hans-Joachim E, Dianxiang Z, Susanne SR. Nuclear ITS Sequences Help Distangle Phyllanthus reticulatus (Phyllanthaceae), an Asian Species not Occurring in Africa, but Introduced to Jamaica. Systematic Botany 2011; 36(1):99-104.

[31] Fawcett W. The public gardens and plantations of Jamaica. Botanical Gazette (Chicago, Ill.) 1897; 24: 345 -369.

[32] Morris D. Botanical institutions of Jamaica . Bulletin of Miscellaneous Information (Royal Gardens, Kew) 1906; 6168.

[33] Rizk AFM. The chemical constituents and economics plants of the Euphorbiaceae. Botanical J Linnean Soci 1987; 94: 293-326.

[34] Petit GR, Cragg GM, Suffness M. Phyllanthostatin 1phyllanthoside prthoacid rearrangement. Journal Org Chem 1985; 50: 5060-5063.

[35] Venkateswaran PS, Millman I, Blumberg BS. Effects of an extract from Phyllanthus niruri on hepatitis and woodchuck hepatitis viruses: in vivo and in vitro studies. Proceedings of the national Academy of science U.S.A. 1987; 84: 274-278.

[36] Blumberg BS, Milllman I, Venkateswaran PS, Thyagarajan SP. Hepatitis B virus and hepatocellular carcinoma treatment of HBV carriers with Phyllanthus amarus. Cancer Detection and Prevention 1989; 14: 195-201.

[37] Thyagarajan SP, Subramanian S, Thirunalasundari T, Venkateswaran PS, Blumberg BS. Effect of Phyllanthus amarus on chronic carriers of Hepatitis B virus. Lancet $2^{\text {nd }}$ 1988; 764-766.

[38] Uiso FC, Kayombo EJ, Mbwambo ZH, Mgonda Y, Mahunnah RLA, Moshi MJ. Traditional healer's knowledge on HIV/AIDS and implications to the management and control of the disease in Arusha, Tanzania. Tanzania Health Research Bulletin 2006; 8(2): 95-100.

[39] Kala CP, Farooquee NA, Dhar U. Prioritization of medicinal plants on the basis of available knowledge, existing practices and use value status in Uttaranchal, India. Biodiver Conserva 2004; 13: 453-469.

[40] Scheinman D. 2002. The ancient and modern worlds unite to fight HIV/AIDS in Tanga, Tanzania. Science in Africa September 2002. www.scienceinafrica.co.za/2002/ september/tanga.htm.

[41] UNAIDS/WHO. 2006. AIDS Epidemic Update. December 2006. Joint United Nations Programme On HIV/AIDS and the World Health Organization, Geneva, Switzerland. http://data.unaids.org/pub/epireport/2006/2006_epiupdate_ en.pdf.

[42] TACAIDS, NBS, and ORC Macro. 2005. Tanzania HIV/ AIDS indicator survey 2003-04. Tanzania Commission for AIDS (TACAIDS), National Bureau of Statistics (NBS) [Tanzania] and ORC Macro, Calverton, Maryland.

[43] Kisangau DP, Lyaruu HVM, Hosea KM, Joseph CC. Use of traditional medicines in the management of HIV/AIDS opportunistic infections in Tanzania: A case in the Bukoba rural district. Ethnobiol Ethnomed 2007; 3:29.
[44] (NIMR) National Institute for Medical Research. 2004. TB/ HIV/Malaria: Challenges to the health systems in Africa in the era of globalization. Proceedings of the 19th Annual joint scientific conference of the National Institute for Medical Research, Arusha International Conference Centre, March 15-17, 2004, Arusha, Tanzania.

[45] (NIH) National Institute of Health. 1994. Fact Sheet: HIV/ AIDS and Alternative Therapies. Office of Alternative Medicine - Fact Sheet No. 7 - June 1994. www.aegis.com/ pubs/cdc_fact_sheets/1994/cdc94033.html.

[46] Mhame PP, Nyigo VA, Mbogo GP, Wiketye VE, Kimaro G, Mdemu A et al.(2004). The management of HIV/AIDSrelated conditions using a traditional herbal preparationmuhanse $m 4{ }^{\circledR}$ in Tanzania: A case study in Dar- es-Salaam, Tanzania. National institute for medical research, Traditional Medicine Research Department, Dar-es-Salaam, Tanzania.

[47] (TUROT) The United Republic of Tanzania. (2003). Kagera Region Socioeconomic Profile. 2nd edition. National Bureau of Statistics (NBS) and Kagera Regional Commissioner's Office, Dar es Salaam.

[48] Kisangau DP, Herrmann TM, Herbert VM, Lyaruu KMH, Joseph CC, Zakaria HM et al. Traditional knowledge, Use Practices and Conservation of Medicinal Plants for HIV/AIDS care in Rural Tanzania. A Journal of plants, people and Applied Research, (Ethnobotany Research \& Applications) 2011: 9: 43-47.

[49] Jayaweera DMA. (1980) Medicinal Plants (Indigenous and Exotic) Used in Ceylon. Part 2. Cactaceae- Fagaceae. National Scinces Council of Sri Lanka, Colombo, pp. 228231.

[50] Pangthong A, Kanjanapothi D, Taylor WC. Ethnombotenical review of medicinal plants from Thai traditional books, part 1st: Plants with anti-inflammatory, anti-asthmatic and antihypertensive properties. J Ethnopharmacol 1986; 18: 213-228.

[51] Ghani A, (2003) Medicinal Plants of Bangladesh with Chemical Constituents and Uses, 2nd ed. Dhaka, Asiatic Society of Bangladesh, pp. 345.

[52] Poopatanapong L, Wongprasert T (1987): Thai Medicinal Plants, Part 5. Bangkok, Chutima Press, pp. 710.

[53] Das BK, Shohel M, Pavel AM, Bhattacharjee R, Das B, Yasmin $\mathrm{T}$ et al. Anti Hepatitis B Viral Activity of Phyllanthus reticulatus. Bangladesh Pharmaceutical Journal, 2011; 14(1): 11-14.

[54] Nadkarni AK. Indian Materia Medica, Popular Prakashan, Bombay. 1976; 1: pp. 948-949.

[55] Nandkarni KM. Indian Materia Medica vol. 2 (1982), p. 948.

[56] Ainslie W. (1826b) Materia Indica. Vol.2. Longman, Rees, Orme, Brown and Greene, London, pp. 239-241.

[57] Dymock WC. (1886) The Materia Medica of Western India. Bombay, pp. 699-704.

[58] Watt G. (1892) A Dictionary of the Economic Products of India, Vol. 6, Part 1. W.H Allen \& Co., London, pp. 217-224.

[59] Dragendorff G. (1898) Die Heilpflanzen der Verschiedenen Volker und Zeiten. Verlag von Ferdinand Enke, Stuttgart, pp. 373-374.

[60] Caius JF. Medicinal and poisonous spurges of India. Journal of the Bombay Nat Hist Soci 1939; 40: 265-313.

[61] Nadkarni KM, Nadkarni AK. (1954) Indian Materia Medica, Vol. 1. $3^{\text {rd }}$. Edn. Popular Book Depot, Bombay, pp.481-484, 947-949.

[62] Kirtikar KR. Basu BD. (1975). Indian Medicinal plants. Vol. 3. $2^{\text {nd }}$ Edn. Jayyed Press, New Delhi, pp. 2217-2227.

[63] Kapur SK. (1983) Medico-botenic survey of medicinal and aromatic plants of Mawphlang (Shillong). Indian Drugs 21,15. Abstract T-9303 from Napralert,college of pharmacy, University of Illinois-Chicago, Chicago, IL

[64] The Wealth of India, Raw Materials, New Delhi: CSIR, NISCOM. Vol. III: 34-36 (1969).

[65] Verdcourt B, Trump, EC. (1969) Common Poisonous Plants of East Africa, Collins, London, pp. 58-59.

[66] Kokwaro JO. (1976) Medicinal Plants of East Africa. East African Literature Bureau, Kampala, pp. 95-97.

[67] Sawhney AN, Khan MR, Ndaalio G, Nkunya MHH, Wevers H. Studies on the rationale of African traditional medicine. 
Part 3. Preliminary screening of Medicinal plants for antifungal activity. Pakistan J Scientific Indus Res 1978; 27: 193196.

[68] Haerdi F. (1964) Native Medicinal Plants of Ulanga District of Tanganyika. Dissertation, Verlag fur Recht und Gesellschaft, University of Basel. Abstract A-5550 from NAPRALERT, College of pharmacy, University of IllinoisChicago, Chicago, IL

[69] Begum T, Rahman MS, Rashid MA. Dhaka Univ. J. Pharm. Sci. 2006; 5: 21.

[70] João BC, Santos ARS, Filho VC, Yunes RA. A Review of the Plants of the Genus Phyllanthus: Their Chemistry, Pharmacology, and Therapeutic Potential, John Wiley \& Sons, Inc., Med Res Rev 1998; 18(4): 225-258.

[71] Vaghasiya Y, Dave R, Chanda S. Phytochemical Analysis of Some Medicinal Plant from Weastern Region of India., Res $J$ Med Plant 2011; 5(5): 567-576.

[72] Shruthi SD, Rajeswari A, Govardhana Raju K, Pavani A, Vedamurthy AB, Ramachandra YL. Phytochemical and antioxidant analysis of leaf extract from Kirganelia reticulata. Int J Pharmacy Pharma sci 2012; 4(3): 608-612.

[73] Chang CC, Lien YC, Liu KC, Lee SS. Lignans from Phyllanthus urinaria. Phytochemistry 2003; 63: 825-833.

[74] Gopinath SM, Rakesh CK, Narasimha TP, Murthy KS, Dayananda. Preliminary phytochemical evaluation of leaf extracts of Gymnema sylvestre, Phyllanthus amarus, Phyllanthus reticulatus of Siddarabetta, Tumkur district, Karnataka, Int J Pharmacog Phytochem Res 2012; 4(3): 109111.

[75] Jain R. Shahla A, Arora R, Jain SC. Phytochemical and Bioactivity of Kirganelia reticulata. Med Aromatic Plant Sci 1998; 20: 740-741.

[76] Hong SL, Wang CY, Chen CK, Lee SS, Chemical Investigation of Phyllanthus reticulatus by HPLC-SPE-NMR and Conventional Methods. Phytochem Anal 2007; 18: 251255.

[77] Pojchaijongdee N, Sotanaphun U, Limsirichaikul S, Poobrasert O. Geraniinic acid derivative from the leaves of Phyllanthus reticulatus. Pharma Biol 2010; 48(7): 740-744.

[78] Hui WH, Li MM, Wong KM (in part), A new compound, 21 $\alpha$-hydroxyfriedel-4(23)-en-3-one and other triterpenoids from Phyllanthus reticulatus. Phytochem 1976; 15(5): $797-$ 798.

[79] Ma JX, Lan MS, Qu SJ, Tan JJ, Luo HF, Tan CH et al. Arylnaphthalene lignan glycosides and other constituents from Phyllanthus reticulatus. J Asian Nat Prod Res 2012; $0(0): 1-5$.

[80] Neves AC, Neves MTC. Some determinations on the leaves of Phyllanthus reticulatus Poir. of Mozambique. Bol Esc Farm Univ Coimbra 1966; 25: 22.

[81] Sangkasila R. 1998. Chemical Constituents and Some Bioactivities of Stem of Phyllanthus reticulatus Poir. MS Thesis. Bangkok, Ramkhamhaeng University.

[82] Omulokoli E, Khan B, Chhabra SC. Antiplasmodial activity of four Kenyan medicinal plants. J Ethnopharmacol 1997; 56: 133-137.

[83] Kumar S, Kumar D, Deshmukh RR, Lokhande PD, More SN, Rangari VD. Antidiabetic potential of Phyllanthus reticulatus in alloxan-induced diabetic mice. Fitoterpia 2008; 79: 21-23.

[84] Das BK, Bepary S, Bidyut K. Datta AK, Chowdhary A, Ali MS, Rouf ASS. Hepatoprotective activity of Phyllanthus reticulatus. Pak J Pharm Sci. 2008; 21(4): 333-337.

[85] Zhong XN, Otsuka H, Ide TE, Hirata TS, Takeda Y. Phytochem 1999; 52: 923

[86] Valcic S, Burr JA, Timmermann BN, Liebler DC, Chem Res Toxicol 2000; 13: 801.

[87] Tian JM, He HP, Di YT, Yang XW, Gao ZL, Hao XJ. $J$ Asian Nat Prod Res 2008; 10: 228.

[88] Zhou YZ, Chen H, Qiao L, Lu X, . Hua HM, Pei YH. Helv Chem Acta 2008; 91: 1277.

[89] Yoshikawa K, Mimura N, Arihara S. Isolation and Absolute Structures of Enantiomeric 1,2-Bis (4-hydroxy-3methoxyphenyl)-1,3-propanediol 1-O-Glucosides from the Bark of Hovenia trichocarpa. J Nat Prod 1998; 61(9): $1137-$ 1139.
[90] Ishikawa T, Sega Y, Kitajima J. Chem Pharm Bull 2001; 49: 840.

[91] Yu Q, Otsuka H, Hirata E, Shinzato T, Takeda Y. Turpinionosides A-E: megastigmane glucosides from leaves of Turpinia ternata Nakai., Chem Pharm Bull (Tokyo). 2002; 50(5): 640-44.

[92] Chern JW, Lee HY, Huang M, Shish FJ. A novel and efficient synthesis of isoguanosine. Tetrahedron Lett 1987; 28: 2151.

[93] Lan MS, Ma JX, Tan CH, Wei S, Zhu DY, Chemical Constituents of Phyllanthus reticulatus, Verlag Helvetica Chimica Acta 2010; 93: 2276-2280.

[94] Pakrashi SC, Bhattacharyya J, Mookerjee S, Samatan TB, Vorbrüggen H. Studies on Indian medical plants -XVIII: The non-alkaloidal constituents from the seeds of Alangium lamarckii Thw. Phytochem 1968; 7(3): 461-466.

[95] Akihisa T, Kojima S, Yokota T, Tamura T. 24-methylene-25methylcholesterol and both C-24 epimers of 24-ethyl-22dehydrocholesterol in a freshwater green alga Hydrodictyon reticulatum. Phytochem 1991; 30(12): 3621-3624.

[96] Zhao M. (2005). Phytochemical studies on medicinal plants, Alisma orientale and Desmodium styracifolium. Hongkong: Chinese University of Hong Kong Press, 675-680.

[97] Jamal AK, Yaacob WA, Laily B, Din A. Chemical Study on Phyllanthus reticulatus. J Phys Sci 2008; 19(2): 45-50.

[98] Seger, CG, Tseng LH, Spraul M, Girtler A, Sturm S, Stuppner H. LC-DAD-MS/SPE-NMR hyphenation. A tool for the analysis of pharmaceutically used plant extracts: identification of isobaric iridoid glycoside regioisomers from Harpagophytum procumbens. Anal Chem 2005; 77: 878885.

[99] Wang CY, Lee SS. Analysis and identification of lignans in Phyllanthus urinaria by HPLC-SPE-NMR. Phytochem Anal 2005; 16: 120-126.

[100] Bieri S, Varesio E, Veuthey JL, Munoz O, Tseng LH, Braumann U, Spraul M, Christen P. Identification of isomeric tropane alkaloids from Schizanthus grahamii by HPLC-NMR with loop storage and HPLC-UV-MS/SPE-NMR using a cryogenic flow probe. Phytochem Anal 2006; 17: 78-86.

[101] Avirutnan W, Pongpan A. The antibacterial activity of some Thai flowers and plants. Mahiodol Univ J Pharma Sci 1983; 10: 81-86.

[102] Bhakuni DS, Dhar ML, Dhar MN, Dhawan BN, Gupta B, Srimali RC. Screening of Indian plants for biological activity.

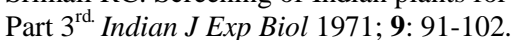

[103] Khan MR, Ndaalio G, Nkunya MHH, Wevers H. Studies on African medicinal plants. Part $1^{\text {st }}$. Preliminary screening of Medicinal plants for antibacterial activity. Planta Medica Suppl 1980; 40: 91-97.

[104] Khan MR, Ndaalio G, Nkunya MHH, Wevers H. Studies on the rationale of African traditional medicines. Part $2^{\text {nd }}$. Preliminary screening of Medicinal plants for anti-gonoccoci activity. Pakistan J Scient Indus Res 1978; 27: 189-192.

[105] Kumar S, Kumar D, Deshmukh RR, Rangari VD. Hypoglycemic activity of roots of Phyllanthus reticulatus in alloxan induced diabetic mice. Int J Plant Sci 2007; 2(1): 184-187.

[106] Rahmatullah M, Khokon CG, Mamun AA, Hossain MT, Ahmed S, Rahman MA, Eva B, Rahman S, Chowdhury MH. A Pharmacological Study on Antinociceptive and Antihyperglycemic Effects of Methanol Extract of Leaves of Phyllanthus Reticulatus Poir. In Swiss Albino Mice. Adv Nat Appl Sci 2010; 4(3): 229-232.

[107] Sankannavar SH, Patil CG. In Vitro studies on diversity of antibacterial activity in some species of Phyllanthus for human pathogenic bacteria. Asian J Exp Biol 2012; 3(3): 607612.

[108] Shruthi SD, Rai PS, Ramachandra YL. In vitro antibacterial activity of Kirganelia reticulate Baill. Against methicillinresistant Staphylococcus aureus. Pharmacophore 2010; 1(2): 123-131.

[109] Maruthappana V, Shreeb KS. In vitro and in vivo antioxidant activity of Phyllanthus reticulatus. Drug Invention Today 2010; 2(6): 303-307. 
[110] Aswatha Ram HN, Shreedhara CS, Gajera FP. Zanwar SB. In Vitro Free Radical Scavenging Potential of Methanol Extract of Entire Plant of Phyllanthus Reticulatus Poir., Pharmacologyonline 2008; 2: 440-451.

[111] Maruthappan V, Shree KS. A report on the antioxidant activity of the powder of the entire plant of Phyllanthus reticulatus Poir. Int J Green Pharmacy 2010; 265-269.

[112] Saha A, Masud MA, Bachar SC, Kundu JK, Datta BK, Nahar L, Sarker S. The Analgesic and Anti-Inflammatory Activities of the Extracts of Phyllanthus reticulatus. Pharmaceu Biol 2007; 45(5): 355-359.

[113] Kumar S, Sharma S, Kumar D, Kumar T, Arya R, Kumar K. Pharmacognostic study and anti - inflammatory activity of Phyllanthus reticulatus Poir. Fruit. Asian Pac J Trop Dis 2012; S332-S335.

[114] Dalziel JM. (1937) The Useful Plants of West Tropical Africa. Secretary of state for the colonie, Crown Agents for the colonies, London, pp 156-158. Reprinted 1948.

[115] Lewis WH, Elwin LMPF. (1977) Medicinal Botany: Plants Affeting Man's Health. John Wiley and sons, New York, pp. 38, 234.

[116] Watt JM, BreyerBrandwijk MG. (1962) The Medicinal and Poisonous Plants of Southern Africa, $2^{\text {nd }}$ Edn. E \& S, Livingstone, Edinburgh, pp. 426-428.

[117] Watt JM, BreyerBrandwijk M.G. (1932) The Medicinal and Poisonous Plants of Southern Africa, E \& S, Livingstone, Edinburgh, p. 99.

[118] Irvine FR, (1961) Woody Plants of Ghana. Oxford University Press, London, pp.246-247.

[119] Broun AF, Massey RE. (1929) Flora of the sudan. Sudan Government office, Wellington House, Buckingham Gate, London. Cited in: Irvine (1961), Duke and Wain (1981).

[120] Dale IR, Greenway PJ. (1961) Kenya Trees and Shrubs. Buchanan's Kenya Estates, Nairobi and Hatchards, London, p. 215.

[121] Morgan WTW. Ethnobotany of the Turkana: use of plants by a pastoral people and their Livestock in Kenya. Economic Botany 1981; 35: 96-130.

[122] Hedberg I, Hedberg O, Madai PJ. Mahigeni KE. Mshiu EN, Samuelsson S. Inventry of Plants used in traditional medicine in Tanzania. 2. Plants of the families DelleniaceaeOpiliaceae. J Ethnophamacol 1983; 9: 105-127.
[123] Chhabra SC, Uiso FC, Mshiu EN. Phytochemical screening of Tanzanian medicinal plants. I. J Ethnopharmacol 1984; 11: $157-179$.

[124] Altschul Siri von Reis (1973) Drug and Foods from littleknown Plants. Notes in Harvard University Herbarium. Harvard University Press, Cambridge, Massachutts, pp. 143145.

[125] Quisumbing E. (1951) Medicinal Plants of the Philippines. Technical Bulletin 16, Philippines Department of Agriculture and Natural Resources, Manila, pp. 527-528.

[126] Padua LSD, Lugod GC, Pancho JV. (1978) Handbook on Philippines Medicinal Plants,Vol. 2. Documentation and Information Section, University of the Philippines, Los Banos, p. 15.

[127] Perry LM, Metzger J. (1980) Medicinal plants of east and southeast Asia: attributed Properties and Uses. MIT Press, Cambridge, MA, pp.149-151.

[128] Lassak EV, McCarthy T. (1983) Australian Medicinal Plants. Methuen Australia, Sydney, pp.125, 138-139, 190.

[129] Jayaweera DMA. (1980) Medicinal Plants (Indigenous and Exotic) Used in Ceylon. Part 2. Cactaceae- Fagaceae. National Scinces Council of Sri Lanka, Colombo, pp. 228231.

[130] Dymock, WC. (1886) The Materia Medica of Western India. Bombay, pp. 699-704.

[131] Petelot A. (1954) Plantes Medicinales du Cambodge, du Laos et du Vietnam. Tome 3(Americantacees a Selaginellacees). Centre de Recherches de Sciences et Technologie, Saigon, pp. 112, 114.

[132] Planchon G, Collin E. (1896) Drogues Simples d'Origine Vegetale. Doin, Paris, p.342.

[133] Burkill IH, Birtwistle W, Foxworthy FW, Scrivenor JB, Watson JG. (1966) A Dictionary of the Economy Products of the Malay Peninsula, Vol.2 Ministry of Agriculture and Cooperatives, Government of Malasiya, Kuala Lumpur, pp. 1747-1749.

[134] Chopra RN, Chopra IC, Verma BS. (1969) Supplement to glossary of Indian Medicinal Plants. Publications and Information Directorate, New Delhi. Cited in: Rizk (1987).

[135] Watt G. (1892) A Dictionary of the Economic Products of India, Vol. 6, Part 1. W.H Allen \& Co., London, pp. 217-224. 